\title{
Developing an Instrument for Iranian EFL Learners' Listening Comprehension Problems and Listening Strategies
}

\author{
Sara Sara Noroozi (Corresponding Author) \\ English Language Department, Faculty of Languages and Linguistics, University of Malaya \\ E-mail: saranoroozi@gmail.com \\ Tam Shu Sim \\ English Language Department, Faculty of Languages and Linguistics, University of Malaya \\ Vahid Nimehchisalem \\ English Language Department, Faculty of Modern Languages and Communication, Universiti Putra Malaysia \\ Gholamreza Zareian \\ Department of English Language and Literature, School of Humanities, Hakim Sabzevari University, Iran
}

Doi:10.7575/aiac.alls.v.5n.3p.63

Received: 02/04/2014

URL: http://dx.doi.org/10.7575/aiac.alls.v.5n.3p.63

Accepted: 13/05/2014

\begin{abstract}
In the body of literature on listening strategies to EFL learners, what seems to be lacking is that the focus is on teaching listening strategies to learners with little attention to their listening comprehension problems. No local research has been conducted on the nature of the Iranian tertiary level students' EFL listening comprehension problems or strategies. Therefore, no instrument is available to investigate these constructs. This paper reports the findings of a study that made an attempt to develop and test an instrument that will aid researchers identify students' specific listening problems and listening strategy repertoire. The instrument was developed by integrating and validating the available instruments in the related literature. The two developed questionnaires were: the Listening Comprehension Problems Questionnaire (LCPQ) and the Listening Strategy Use Questionnaire (LSUQ). Problems related to designing and testing this instrument is shared and the modifications made to it are presented. The instrument is expected to be useful for researchers interested to study the area of EFL listening in a similar setting.
\end{abstract}

Keywords: Questionnaire validation, EFL listening strategies, Listening problems

\section{Introduction}

Studies on English as a Foreign Language (EFL) listening skills usually focus on teaching listening strategies to language learners in order to address their listening problems (Goh, 2000; Hassan, 2000; Liu, 2002). However, it should be noted that before we teach strategies to learners, we should understand their specific areas of difficulty as well as the strategies that they are already aware of. Unfortunately, research on the Iranian tertiary level students' listening comprehension problems and strategies is limited. As a result, no suitable instrument is available in the literature to support researchers in investigating these students' listening difficulties and strategies.

This paper reports the findings of a study in which two questionnaires, namely, the Listening Comprehension Problems Questionnaire (henceforth LCPQ) and the Listening Comprehension Strategy Use Questionnaire (henceforth LSUQ) were developed based on the available theory, literature, and previous similar instruments. The next section presents the procedure that was followed to develop and test the instrument.

\section{Procedure}

The procedure that was followed in developing and testing the instrument included the following phases:

1. Reviewing the related literature,

2. Setting the ground rules for developing the instrument,

3. Constructing the questionnaires,

4. Modifying the questionnaires based on the feedback elicited from a panel of experts,

5. Field-testing the questionnaires on a random sample of the target students, and finally,

6. Refining the instrument.

What follows is a report of how the questionnaires were developed and then tested following the phases mentioned above. 


\section{Reviewing the literature}

The instrument to be discussed in this paper consists of two questionnaires, the Listening Comprehension Processing Problems Questionnaire (henceforth LCPQ) and Listening Comprehension Strategy Use Questionnaire (henceforth LSUQ).These questionnaires were developed based on a detailed literature review of similar studies on listening such as Goh (2000), Hasan (2000), and Liu (2002), Bacon (1992), Cohen, Oxford, and Chi (2005), Vandergrift (1997, 2003, 2007) and Vandergrift et al. (2006). The first questionnaire, LCPQ, adapts items from the Survey of the Problems of English Language Listening (Liu, 2002) and is based on listening problem categories identified by Goh (2000). Similarly, LSUQ, as the second questionnaire is constructed on the basis of several listening strategy inventories by Bacon (1992), Vandergrift (1997, 2003), and Cohen, Oxford, and Chi (2005) as well as items adapted from the Metacognitive Awareness Listening Questionnaire by Vandergrift et al. (2006). Table 1 shows the item numbers in LCPQ and LSUQ that were constructed on the basis of the literature review and adopted or adapted from the existing related instruments.

Table 1. Items of LCPPQ and LSUQ

\begin{tabular}{lcccc}
\hline \multirow{2}{*}{ Questionnaire } & Constructed & Adopted & Adapted & Total \\
\cline { 2 - 5 } LCPS & $8-9,14-16,18-20$, & $1-6,10-13,17,21-$ & $7,27-29,31$ & 31 \\
\hline LSUQ & 25,26, & 24,30 & $20,31-15,20,23-$ & 38 \\
\hline
\end{tabular}

The first questionnaire was based on Anderson's listening theory. According to Anderson (1995, cited in Graham and Macaro, 2008, p.748), there are three phases involved in listening comprehension: perceptual processing, parsing, and utilization. During perceptual processing, listeners focus on the text, segment the phonemes from the speech stream, and keep them in their echoic memory. In the second phase, parsing, listeners match this information in their echoic memory with the linguistic information in their long-term memory in order to create meaningful mental representations. Finally, in the phase of utilization, listeners relate the information which they have collected in the previous phases to their schemata in order to understand what they have just heard (Anderson, 1995). Listening comprehension problems refer to the drawbacks that may happen at these three cognitive stages (Goh, 2000).

As for the listening strategies, Vandergrift (1997) offers a taxonomy of listening strategies that includes metacognitive, cognitive, and socio-affective strategies. According to Vandergrift (2003), cognitive strategies involve mental activities for using the language to complete a task. When students use known words to guess the meaning of unknown vocabulary items in a text, they use a cognitive strategy. Likewise, focusing on some parts of the text while ignoring other less important parts is a cognitive strategy. Metacognitive strategies are mental activities that direct learners in their language learning process. For instance, when learners become aware of the fact that reading some background materials will prepare them to listen more effectively, they employ a metacognitive listening strategy. Another example would be learning to focus on the main topic and the keywords while ignoring distracters like noise and other people around. Finally, socio-affective strategies refer to activities that involve interaction with other individuals or affective control in language learning. Common examples of socio-affective strategies include working with others to solve one's listening problems and learning to relax when feeling afraid of not understanding others. Anderson's (1995) theory along with Vandergrift's (1997) taxonomy provided the theoretical foundation for the present developmental study.

\section{Setting the ground rules}

Questionnaires are useful instruments that can provide insights into learner awareness of their process of listening (Liu, 2002; Hassan, 2000; Mareschal, 2007) as well as listening comprehension problems and listening strategies. Questionnaires have the advantage of "quickly providing information on a wide variety of language learning variables" (Dornyei, 2003 cited in Mareschal, 2007, p.50). Before constructing a questionnaire, it is important to set a number of ground rules to ensure the usefulness of the outcome.

The ground rules based on which the items of the questionnaires were constructed were determined based on the literature on listening comprehension in general (Feyton, 1991; Field, 2008a), learners' listening comprehension problems (Goh, 2000; Hasan, 2000; Liu, 2002; Field, 2004), listening strategies (Berne, 2004; Vandergrift, 2007; Macaro, Graham, \&Vanderplank, 2007), and the related literature on second language research methodology (Dörnyei, 2003; Mackey \& Gass, 2005; McKay, 2006, Dörnyei, 2007). These rules included:

1. Clarity: The instructions and items should be clear. Definitions, synonyms, or examples were added next to difficult terms. In addition, the translation of each item in Persian was added below its English version. The translation was carried out by the first author and validated by two Persian-speaking lecturers, one English language lecturer (holding a PhD in TESL) as well as one Persian language lecturer.

2. Economy: The questionnaires should be as concise as possible. As suggested by Dörnyei (2003, pp. 18-19), "long questionnaires can be counterproductive". 
3. Appropriate layout: The "space economical font" of 11-point Times New Roman should be used and placing the "response options next to the questions not below" (Dörnyei, 2003, p.14).

4. Construct Validity: The domains and/or items of an instrument should be informed by established and relevant theory. The listening comprehension problem items were developed according to Anderson's (1995) listening theory (which was also followed by Goh, 2000). Additionally, the listening strategy items were based on Vandergrift's $(1997,2003)$ order in his taxonomy;

5. Internal reliability: This can be improved by removing ambiguous items and/or terms and by avoiding double-barreled questions, which raise more than one issue.

6. Ease of tabulation and interpretation of the responses: A Likert scale should be used in which the respondents are required to rate the frequency of encountering a specific listening comprehension problem or using a particular listening strategy on a scale of 1 (never) to 5 (always).

Following these principles, the researchers expected to come up with an instrument that was high in validity, reliability, and practicality.

\section{Constructing the questionnaires}

Some items were adopted from the existing questionnaires on listening comprehension problems and strategies if they were clear and relevant to the Iranian context. Others were adapted by the researchers to make them more comprehensible and more appropriate to the Iranian context. As a result, two item pools of 31 for LCPQ and 38 for LSUQ were developed to be validated by a panel of experts discussed in the next section.

\section{Modifying the questionnaires}

While qualitative method was employed in constructing the instrument, both qualitative and quantitative methods were used in validating it. After the construction of items based on a literature review and the adoption or adaptation of other items from the existing related instruments, the questionnaires were validated through expert judgment and field-test. These would help the researchers obtain feedback from both the experts and the students on the validity, reliability, and item clarity of the instrument (Dörnyei, 2003; Vandergrift et al., 2006; Creswell, 2008).

The first draft of the instrument was presented or e-mailed to $10 \mathrm{EFL}$ experts, who judged on the "redundancy, content validity, clarity, and readability" (Dörnyei, 2003 cited in Vandergrift et al., 2006, p. 440) of its items. Seven out of the ten experts evaluated the instrument providing several useful comments. Tables 2 and 3 summarize the modifications made to the first draft of the instrument based on the experts' comments. These comments involved rewording, rearranging, deleting, as well as adding items, examples, definitions, and/or easier terms.

Table 2. Expert Comments on LCPQ

\begin{tabular}{lll}
\hline \multicolumn{2}{c}{ Comments } & \multicolumn{2}{c}{ Modifications } \\
\cline { 1 - 2 } General Area & \multicolumn{1}{c}{ Details } & \multicolumn{2}{c}{ Items 28 \& 31 are similar. In both, the } & In item 31, "main idea" was changed to \\
& "main ideas" are used. & "supporting ideas".
\end{tabular}

The words "catch" in item 2, "recall" in They were changed into "understand", item 11, and "subsequent" in item 25 are "remember", and "later" respectively.

1 Rewording difficult to understand.

The word "text" has been used The words "material" in item 16 and inconsistently. It was sometimes "input" in items $25 \& 29$ were reworded as replaced by "material" in item 16 or by "text".

"input" in items $25 \& 29$.

The items in the perception section are not arranged from general to specific: concentration, sounds, and words.

2 Rearranging $\quad$ Item 29 should be moved and replaced These items were rearranged accordingly. by item 31 for a better sequence because item 31 is more general.

Deleting
Redundant Words, In item 23, the phrase "or concepts" is The phrase "or concepts" was deleted. redundant. 
Phrases, or Items Items 5 and 6 are related to speaking

rather than listening problems.

Item 7 is not appropriate since Iranian Items 5-7 were deleted. teachers are not comparable to native models.

Items 9 and 17, 2 and 13,8 and 15 are One item was removed from each group. the same.

\begin{tabular}{|c|c|c|c|}
\hline 4 & $\begin{array}{l}\text { Adding Some } \\
\text { Necessary Words } \\
\text { or Phrases }\end{array}$ & $\begin{array}{l}\text { Item } 30 \text { is incomplete and the phrase "of } \\
\text { the text" is missing. } \\
\text { The phrase "both audio and video" } \\
\text { should be added to the instruction. }\end{array}$ & The phrases were added. \\
\hline 5 & Typos & Items $8,14,20, \& 30$ include errors. & Typos were corrected. \\
\hline
\end{tabular}

Table 3. Expert Comments on LSUQ

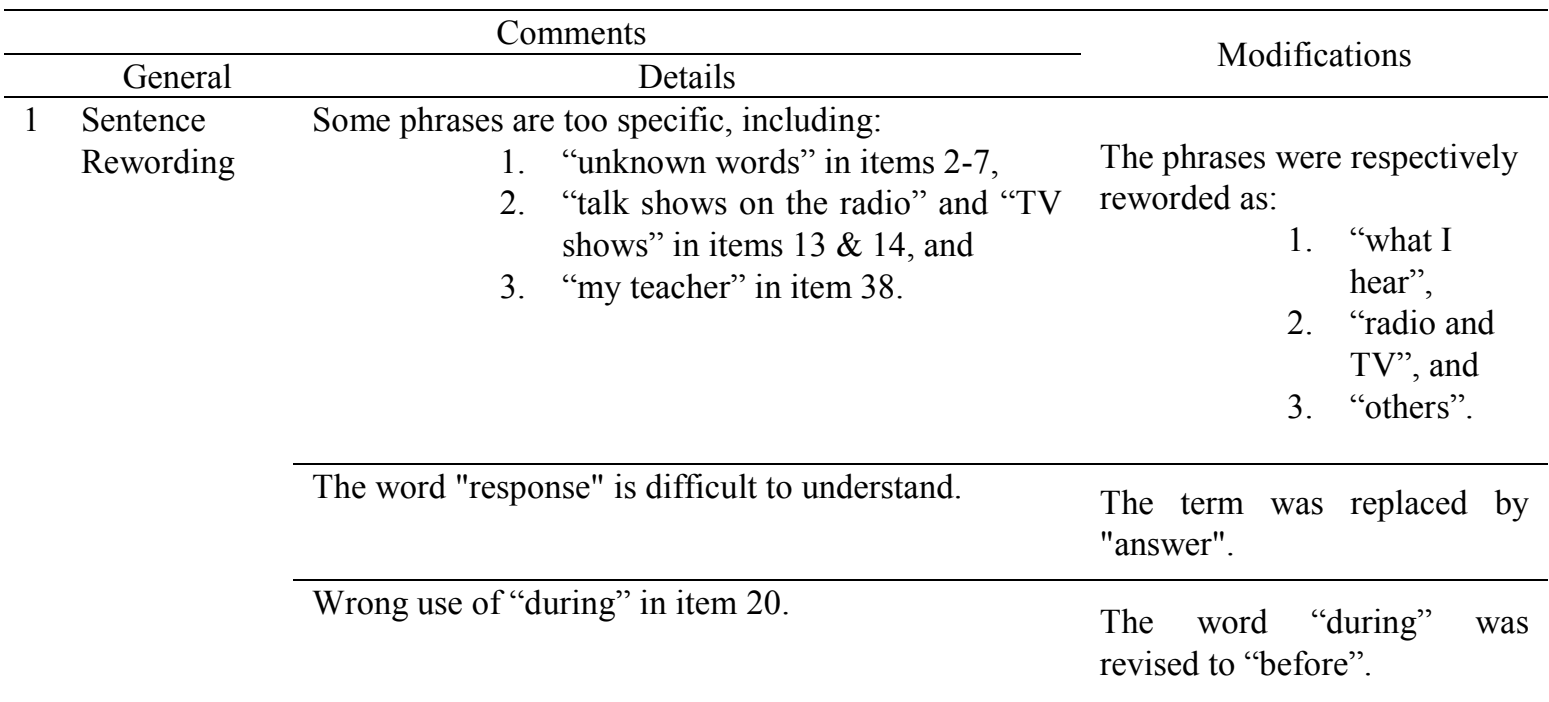

The phrase "in an oral text" in item 5, the words

"usually" in item 32, "paralinguistics" in item 3, and

2 Redundant the phrase "right away" from item 27 are redundant.

Phrases, or $\quad$ Item 32, 33, and 34 are similar

Items
The phrase "both audio and video" should be added to the instruction.

The phrase "other things or people around me", the

Adding Some word "mental" (mental summary), and the phrase "try to" should be added to items 24,8 , and 27 ,

3 Necessary respectively.

Phrases

\section{These were all deleted.}

These were merged into one item.

Example is needed for item 6.

An example was added.

\begin{tabular}{lll}
\hline 4 & Typos & Items 9 and 16 include errors.
\end{tabular}

Appendices A and B show a detailed account of the original items and their revised versions in LCPQ and LSUQ in the order they appear in Tables 2 and 3. As a result of expert judgment, the LCPQ and LSUQ were reduced to 24 and 35 items, respectively.

\section{Field-testing the questionnaires}

Both qualitative and quantitative methods were employed to field-test the instrument. The two questionnaires were tested for the following purposes:

1.To receive feedback on the questionnaires from a number of students in terms of clarity of their instructions, difficulty of their items, time needed for their administration, among others (as recommended by Creswell, 2008);

2.To discover the problems that the respondents may encounter while responding to the items (Liu, 2002); 
3.To determine the reliability of the questionnaires through test-retest method (Dörnyei, 2003); and

4.As a corollary to these three purposes, to modify and refine the questionnaires (Dörnyei, 2003).

The field-test participants were a randomly selected sample of tertiary level students $(n=20)$. They were aged 19-24, and $70 \%$ of them were females. The two questionnaires were administered to these students twice with a time interval of two weeks for determining the reliability through test-retest method. This helped the researchers receive useful feedback and information on the clarity of instructions, the difficulty of items, the time needed for the instrument administration, the questionnaire layout, and for better administration. Following McBride (2007, p.110), the students were required to write about their "general impressions" of the questionnaires, suggestions for improving them, and ideas about the instructions, difficulty level, time limit, and layout on a separate critique sheet attached to the questionnaires. Moreover, they were asked to circle the number of the survey items that they felt were difficult, unclear or ambiguous and were encouraged to make necessary changes for more clarity on the questionnaires.

Before administration, the teacher was asked to present a listening activity to the students, "so that students would have a specific task on which to base their responses" (Vandergrift et al, 2006, p. 441). The first author then explained about the importance of the research and the need for the students to cooperate and respond carefully in order to make the results of the research more reliable. She then answered students' questions about the project. The students signed consent forms and were assured that all data collected would be kept anonymous. The questionnaires were distributed to the students. On average, it took them approximately 35 minutes to complete these procedures. Students were asked to double-check survey responses and return the questionnaires. The response rate was $100 \%$ and none of the completed questionnaires had to be discarded.

\section{Refining the instrument}

Administrating the questionnaires to the students provided some important information regarding the clarity and difficulty of the items, the time needed for administration, the layout, the necessity of some oral reminders, and the type of administration. This information was obtained both orally through the students' questions or reactions, and in written form on the critique sheet. Table 4 summarizes these findings:

Table 4. Learners' feedback on LCPQ and LSUQ

\begin{tabular}{|c|c|c|c|}
\hline \multicolumn{3}{|r|}{ Feedback } & \multirow[t]{2}{*}{ Modifications } \\
\hline & General & Details & \\
\hline \multirow{4}{*}{$\stackrel{\overbrace{}}{0}$} & \multirow[t]{2}{*}{$\begin{array}{l}\text { Item clarity or } \\
\text { difficulty }\end{array}$} & $\begin{array}{l}\text { The explanation related to the } \\
\text { transactional listening should be } \\
\text { highlighted or underlined. Some } \\
\text { learners require oral explanation for } \\
\text { it. }\end{array}$ & The explanation was added \\
\hline & & $\begin{array}{l}\text { Item } 20 \text { raises more than one } \\
\text { question and sounds ambiguous. }\end{array}$ & It was reworded. \\
\hline & $\begin{array}{l}\text { Required } \\
\text { administration } \\
\text { time }\end{array}$ & $\begin{array}{l}\text { Students need a minimum of } 10 \\
\text { minutes to complete the two } \\
\text { questionnaires. }\end{array}$ & $\begin{array}{l}\text { The recommended administration } \\
\text { time was set at } 15 \text { minutes. }\end{array}$ \\
\hline & Layout & Suitable & - \\
\hline \multirow{6}{*}{ 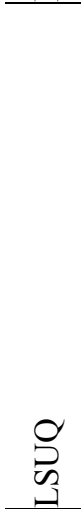 } & \multirow[t]{4}{*}{$\begin{array}{l}\text { Item clarity or } \\
\text { difficulty }\end{array}$} & $\begin{array}{l}\text { Item } 30 \text { is difficult and raises more } \\
\text { than one question. }\end{array}$ & It was reworded. \\
\hline & & Examples should be used for item 5 . & An example was added. \\
\hline & & $\begin{array}{l}\text { Highlight the important parts in } \\
\text { items } 27 \text { and } 28 \text {. }\end{array}$ & The related parts were highlighted. \\
\hline & & Item 17 is confusing. & It was reworded. \\
\hline & $\begin{array}{l}\text { Required } \\
\text { administration } \\
\text { time }\end{array}$ & $\begin{array}{l}\text { Students need a minimum of } 10 \\
\text { minutes to complete the two } \\
\text { questionnaires. }\end{array}$ & $\begin{array}{l}\text { The recommended administration } \\
\text { time was set at } 15 \text { minutes. }\end{array}$ \\
\hline & Layout & Suitable & - \\
\hline
\end{tabular}

Since some students had not answered item 19 in LCPQ and items 3, 10, and 17 in LSUQ, these items were deleted after consultation with the experts. Indeed, the information to be elicited by these items could be obtained by other similar items. Consequently, the final number of items was 23 for LCPQ and 32 for LSUQ.

Having fine-tuned the questionnaires, following the steps mentioned above, the researchers tested the internal reliability using SPSS (Version16). High Cronbach's alpha indices of internal consistency were obtained for LCPQ (0.80) and LSUQ (0.87). 


\section{Conclusion}

The present study sought to develop and validate an instrument, consisting of two questionnaires, to identify Iranian tertiary level EFL learners' listening comprehension problems and strategies. The previous instruments, the available theory and the related literature were reviewed to construct the items. The questionnaires were validated by a panel of experts, based on whose feedback modifications were made to the questionnaires. This was followed by a test which provided useful information for the researchers to further fine-tune the instrument by observing how it works in the actual test setting.

The paper is expected to have methodological implications, particularly for instrument developers in the area of language studies. The ground rules and the developmental procedure followed in this study can be considered in similar studies that aim at developing instruments. Researchers interested in the area of EFL listening skill may also find the instrument useful for testing EFL learners' listening problems and strategies in their own learning context. The instrument may even be used in ESL learning context with some modifications.

Likewise, language teachers can also benefit from the results of this study. The items of the present instrument can help teachers. They may use the instrument as a helpful checklist to be referred to in times they need to diagnose their learners' listening comprehension problems or to find out which listening strategies their more successful learners use that distinguish them from less successful learners.

A final implication of this study is that listening problems and strategies should not be approached in isolation. The instrument consists of a questionnaire that focuses on learners' listening comprehension problems and another questionnaire which investigates their listening strategies. Combining the two constructs in one instrument means that learners' listening strategies should not be taught or researched in isolation from their listening comprehension problems.

Further research with a larger sample size will allow using more quantitative methods to validate the present instrument. The results of such validity tests will provide further empirical proof on the usefulness of the present instrument.

\section{References}

Anderson, J. R. (1995). Cognitive psychology and its implications ( $2^{\text {nd }}$ ed.) New York: Freeman.

Bacon, S. M. (1992). The relationship between gender, comprehension, processing strategies, and cognitive and affective response in foreign language listening. Modern Language Journal, 76(2), 160-177.

Berne, J. E. (2004). Listening comprehension strategies: A review of the literature. Foreign Language Annals, 37(4), 521-533.

Cohen, A. D., Oxford, R. L., \& Chi, J. C. (2005). Maximizing study abroad: Language strategy use inventory. University of Minnesota: Center for Advanced Research on Language Acquisition.

Creswell, J. W. (2008). Educational research: Planning, conducting, and evaluating quantitative and qualitative research ( $3^{\text {rd }}$ ed.). NJ: Pearson Education International.

Dörnyei, Z. (2003). Questionnaires in second language research: Construction, administration and processing. Mahwah, NJ: Erlbaum.

Dörnyei, Z. (2007). Research methods in applied linguistics. Oxford: Oxford University Press.

Field, J. (2004). An insight into listeners' problems: Too much bottom-up or too much top-down? System, 32(3), 363377.

Goh, C. C. M. (2000). A cognitive perspective on language learners' listening comprehension problems. System, 28(1), 55-75.

Hasan, A. (2000). Learners' perceptions of listening comprehension problems. Language, Culture and Curriculum, 13(2), 137-153.

Liu, N. F. (2002). Processing problems in L2 listening comprehension of university students in Hong Kong. (Doctoral dissertation, Hong Kong Polytechnic University).

Mackey, A. \& Gass. S. M. (2005). Second language research: Methodology and design. Mahwah, NJ: Erlbaum.

Mareschal, C. (2007). Student perceptions of a self-regulatory approach to second language listening comprehension development. (Doctoral dissertation, University of Ottawa).

McBride, K. A. (2007). The effect of rate of speech and CALL design features on EFL listening comprehension and strategy use (Doctoral dissertation, The University of Arizona).

McKay, S. L. (2006). Researching second language classroom. Mahwa, NJ: Lawrence Erlbaum Associates.

Vandergrift, L. (1997). The comprehension strategies of second language (French) listeners: A descriptive study. Foreign Language Annals, 30(3), 387-409.

Vandergrift, L. (2003). Orchestrating strategy use: Toward a model of the skilled second language listener. Language Learning, 53(3), 463-496.

Vandergrift, L. (2007). Recent developments in second and foreign language listening comprehension research. Language Teaching, 40(3), 191-210.

Vandergrift, L., Goh, C., Mareschal, C. J., \& Tafaghodtari, M. H. (2006). The metacognitive awareness listening questionnaire: Development and validation. Language learning, 56(3), 431-462. 
Appendix A: Original and revised items in LCPQ

\begin{tabular}{|c|c|}
\hline Original items & Revised items \\
\hline $\begin{array}{l}\text { 28. I get confused about the key ideas in the } \\
\text { message. } \\
\text { 31. I find it difficult to get the main ideas of what I } \\
\text { hear. }\end{array}$ & $\begin{array}{l}\text { 24. I find it difficult to get the supporting ideas of } \\
\text { what I hear. }\end{array}$ \\
\hline 2. There are too many words I cannot catch. & 2. There are too many words I cannot understand. \\
\hline $\begin{array}{l}\text { 11. I am slow to recall the meaning of words that } \\
\text { sound familiar. }\end{array}$ & $\begin{array}{l}\text { 5. I am slow to remember the meaning of words } \\
\text { that sound familiar. }\end{array}$ \\
\hline $\begin{array}{l}\text { 25. I do not understand subsequent parts of input } \\
\text { because of earlier problems. }\end{array}$ & $\begin{array}{l}\text { 17. I do not understand later parts of text because } \\
\text { of earlier problems. }\end{array}$ \\
\hline $\begin{array}{l}\text { 16. I miss the next part of the material while } \\
\text { thinking about the meaning. }\end{array}$ & $\begin{array}{l}\text { 9. I miss the next part of the text while thinking } \\
\text { about the meaning. }\end{array}$ \\
\hline $\begin{array}{l}\text { 25. I do not understand subsequent parts of input } \\
\text { because of earlier problems. }\end{array}$ & $\begin{array}{l}\text { 17. I do not understand later parts of text because } \\
\text { of earlier problems. }\end{array}$ \\
\hline 29. I find it difficult to get the details of the input. & 22. I find it difficult to get the details of the text. \\
\hline $\begin{array}{l}\text { 23. I find it difficult to follow unfamiliar topics or } \\
\text { concepts. }\end{array}$ & 15. I find it difficult to follow unfamiliar topics. \\
\hline $\begin{array}{l}\text { 5. The speaker does not speak loud enough. } \\
\text { 6. The speaker does not pause long enough. } \\
\text { 7. Iranian speakers are easier to understand than } \\
\text { native speakers. }\end{array}$ & Deleted \\
\hline
\end{tabular}

Appendix B: Original and revised items in LSUQ

\begin{tabular}{|c|c|}
\hline \multicolumn{1}{|c|}{ Original items } & Revised items \\
\hline $\begin{array}{c}\text { 2. I use the tone of voice (the rise and fall of voice) } \\
\text { to guess the meaning of unknown words in an } \\
\text { utterance. }\end{array}$ & $\begin{array}{c}\text { 2. I use the tone of voice to guess the meaning of } \\
\text { what I hear. }\end{array}$ \\
\hline $\begin{array}{l}\text { 13. I listen to talk shows on the radio in the target } \\
\text { language. }\end{array}$ & 13. I watch TV in the target language. \\
\hline $\begin{array}{l}\text { 14. I watch TV shows in the target language. } \\
\begin{array}{l}\text { 6. I use material in the response sheet to guess the } \\
\text { meaning of unknown words. }\end{array}\end{array}$ & $\begin{array}{c}\text { 5. I use material in the answer sheet (e.g. the } \\
\text { printed items, choices and pictures) to guess } \\
\text { the meaning of what I hear. }\end{array}$ \\
\hline $\begin{array}{l}\text { 5. I use relationships between speakers in an oral } \\
\text { text to guess the meaning of unknown words. }\end{array}$ & $\begin{array}{c}\text { 5. I use relationships between speakers to guess the } \\
\text { meaning what I hear. }\end{array}$ \\
\hline $\begin{array}{c}\text { 24. I decide to focus on the topic and ignore the } \\
\text { distractors such as noise and others around me. }\end{array}$ & $\begin{array}{c}\text { 23. I decide to focus on the topic and ignore the } \\
\text { distractors such as people and things around } \\
\text { me. }\end{array}$ \\
\hline $\begin{array}{l}\text { 6. I use material in the response sheet to guess the } \\
\text { meaning of unknown words }\end{array}$ & $\begin{array}{c}\text { 5. I use material in the answer sheet (e.g. the } \\
\text { printed items, choices and pictures) to guess } \\
\text { the meaning of what I hear. }\end{array}$ \\
\hline
\end{tabular}

